\title{
PERSOALAN YANG TERSISA DALAM SISTEM PRESIDENSIIL PASCA AMANDEMEN UUD 1945
}

\author{
Nabitatus Sa'adah \\ Fakultas Hukum, Universitas Diponegoro \\ Jl. Prof. H. Soedarto, S.H, Tembalang, Semarang \\ n4b1t4tuz@yahoo.com
}

\begin{abstract}
State history shows that before the amendment to the 1945 Constitution there was an uncertainty in the system of government adopted. The amendment to the 1945 Constitution of the government system adopted in Indonesia was agreed to be emphasized by choosing a presidential system of government. Although in the amendments to the 1945 Constitution to the fourth amendment it was seen that there was an endeavor towards purifakasi presidential systems but there were still a number of things left behind and considered still not supporting the implementation of presidential systems and this certainly had implications in the constitutional system. This can be seen in the legislative mechanism as stipulated in Article 20 paragraph (2.3) of the 1945 Constitution of the Republic of Indonesia. Another thing that is still incompatible with the presidential system is related to the multi-party system adopted. The multi-party system can lead to unhealthy state practices both in drafting the cabinet, legislation, implementing government policies.
\end{abstract}

Keywords: Presidential System; Amendment

\begin{abstract}
Abstrak
Sejarah ketatanegaraan menunjukkan sebelum adanya amandemen UUD 1945 ada ketidaktegasan sistem pemerintahan yang dianut. Perubahan UUD 1945 sistem pemerintahan yang dianut di Indonesia disepakati dipertegas dengan memilih sistem pemerintahan presidensiil. Meskipun dalam perubahan UUD 1945 sampai perubahan keempat terlihat adanya upaya kesungguhan menuju purifakasi sistem presidensial tetapi masih ada beberapa hal yang tertinggal dan dianggap masih belum mendukung pelaksanaan sistem presidensial dan hal demikian tentunya mempunyai implikasi dalam sistem ketatanegaraan. Hal ini terlihat dalam mekanisme legislasi sebagaimana diatur dalam Pasal 20 ayat $(2,3)$ UUD NRI tahun 1945. Hal lain yang masih belum sesuai dengan sitem presidensiil adalah terkait dengan sistem multi partai yang dianut. Sistem multi partai dapat menimbulkan praktik kenegaraan yang tidak sehat baik dalam penyusunan kabinet, legislasi, implementasi kebijakan pemerintah.
\end{abstract}

Kata Kunci : Sistem Presidensiil; Amandemen 


\section{A. Pendahuluan}

Pada umumnya konstitusi suatu negara mengatur beberapa hal pokok antara lain, pertama, adalah jaminan terhadap hak-hak asasi manusia dan warga negara, kedua, ditetapkannya susunan ketatanegaraan suatu negara yang bersifat fundamental dan yang ketiga adalah pembagian dan pembatasan tugas ketatanegaraan yang juga bersifat fundamental (Sri Soemantri, 1997). Di dalam suatu konstitusi juga dapat tersirat adanya sistem pemerintahan yang dianut suatu negara. Pengertian sistem pemerintahan itu sendiri adalah suatu tatanan utuh yang terdiri atas berbagai komponen pemerintahan yag bekerja saling bergantungan dan mempengaruhi dalam pencapain tujuan negara (Mahmuzar, 2010). Mahfud MD mengatakan bahwa sistem pemerintahan dipahami sebagai suatu sistem hubungan tata kerja antar lembaga-lembaga negara (Moh.Mahfud, 1993). Hamid Attamimi mengemukakan dalam membicarakan sistem pemerintahan pada hakekatnya membicarakan sistem kerja atau fungsi pemerintahan yang dilakukan oleh Presiden dalam hubungannya dengan lembaga negara lainnya (Attamimi, 2009). Berdasarkan uraian di atas dapat dikatakan bahwa membicarakan mengenai sistem pemerintahan adalah membicarakan hubungan antar lembaga negara.

Berbicara mengenai lembaga negara sangatlah terkait dengan adanya pembagian atau pemisahan kekuasaan dalam suatu negara. Pemisahan kekuasaan merupakan hal yang sangat penting dalam penyelenggaraan pemerintahan. Adanya distribusi kekuasaan tersebut dimaksudkan agar terdapat keseimbangan kekuasaan antara satu lembaga dengan lembaga lain (S.Sunarto, 2016). Ajaran teori pemisahan kekuasaan yang terkenal adalah ajaran Trias Politca sebagaimana yang dikemukakan oleh Montesquie yaitu kekuasaan legislatif yaitu kekuasaan membentuk undang-undang, kekuasaan eksekutif yaitu kekuasaan menjalankan undang-undang serta kekuasaan yudikatif yaitu kekuasaan menegakkan hukum (Mustafa, 2001). Berbicara tentang ketiga pembagian kekuasaan tersebut dalam kaitannya dengan sistem pemerintahan maka hubungan yang paling dominan terlihat adalah hubungan antara lembaga eksekutif dan legislatif. Berkaitan dengan hal ini Usep Ranuwijaya menegaskan bahwa sistem pemerintahan adalah sitem hubungan antara eksekutif dan legislatif (Ranuwijaya, 2001). Hubungan antara lembaga eksekutif dan legislatif sangatlah dipengaruhi adanya sistem pemerintahan yang dianut. Sistem Pemerintahan pada dasarnya dapat dibedakan dalam berbagai kategori, secara konvensional sistem pemerintahan dibedakan dalam dua bentuk yaitu sistem presidesiil dan sistem parlementer. Di luar kedua sistem ini terdapat sistem pemerintahan campuran. Hal demikian sebagaimana di katakan oleh Jimly Asshidiqie bahwa sistem pemerintahan suatu negara dapat dibedakan menjadi tiga kategori yaitu sistem pemerintahan presidensial (presidential system), sistem pemerintahan parlementer (parliamentary system) dan sistem campuran (Mixed System atau Hibrid System) (Jimly Asshiddiqie, 2007).

Dalam sejarah ketatanegaraan, Indonesia pernah mempraktikkan dua model sistem pemerintahan yaitu sistem presidensiil dan parlementer. Tahun 1945 sampai dengan tahun 1959 Indonesia menerapkan sistem pemerintahan parlementer dengan tiga konstitusi yang berbeda yaitu Undang-undang Dasar 1945 (1945 - 1949), Konstitusi Sementara Republik Indonesia Serikat (1949 1950) dan Undang-undang Dasar Sementara Republik Indonesia 1950 (1950 - 1959). Ketika kembali pada Undang-undang Dasar 1945 melalui Dekrit Presiden 5 Juli 1959, Indonesia memakai sistem pemerintahan presidensiil, meskipun di kalangan pakar Hukum Tata Negara memberi beberapa penafsiran yang berbeda mengenai sistem yang dianut pemerintah negara kita sebagaimana yang tertuang dalam UUD 1945 tersebut dengan mendasarkan pada beberapa karakter yang ada. Ada kelompok pakar Hukum Tata Negara yang mengatakan bahwa sistem pemerintahan yang dianut Indonesia adalah sistem pemerintahan presidensial dan ada yang mengatakan bahwa sistem pemerintahan negara kita adalah sistem pemerintahan campuran. Adanya kerancuan 
inilah maka MPR hasil pemilu 1999 menyepakati untuk mempertegas sistem pemerintahan yang dianut oleh negara kita dengan kesepakatan untuk memilih sistem pemerintahan presidensial sebagai sistem pemerintahan dengan beberapa alasan antara lain pertama, sistem presidensial yang dianggap mampu menciptakan stabilitas nasional pemerintahan; kedua, Bangsa Indonesia mempunyai pengalaman traumatis ketika berlaku sistem pemerintahan parlementer menurut UUD Sementara 1950; ketiga, sistem pemerintahan parlementer dianggap sebagai aliran pemikiran demokrasi liberal; keempat, pemilihan langsung memperkuat legitimasi pemerintah karena mendapat mandat langsung dari rakyat; kelima, sistem pemerintahan presidensial dianggap sesuai dengan sistem pemerintahan yang sebenarnya dikehendaki para pendiri bangsa (The Founding Fathers) meskipun formatnya tidak sebagaimana sistem presidensial pada umumnya (Isra, 2010).

Kesepakatan untuk memilih sistem presidensial tersebut akhirnya ditindak lanjuti dengan berbagai upaya untuk melakukan pemurnian sistem presidensial. Keseriusan melakukan upaya purifikasi tersebut terlihat dalam setiap perubahan UUD 1945 yang pernah dilakukan. Meskipun dalam perubahan UUD 1945 sampai perubahan keempat terlihat adanya upaya kesungguhan menuju purifakasi sistem presidensial tetapi masih ada beberapa hal yang tertinggal dan dianggap masih belum mendukung pelaksanaan sistem presidensial dan hal demikian mempunyai implikasi dalam sistem ketatanegaraan kita, hal inilah yang menurut penulis menarik untuk dibahas.

Berdasarkan latar belakang di atas maka permasalahan yang muncul adalah: (1) Persoalan-persoalan apa sajakah yang masih tertinggal dalam rangka purifikasi sistem presidensial di Indonesia?; dan (2) Bagaimana implikasi persoalan yang tertinggal tersebut dalam sistem ketatanegaraan kita?

Penulisan ini bertujuan memberi masukan terhadap beberapa hal yang dianggap belum konsisten terkait dianutnya sistem presidensiil. Tulisan ini berbeda dengan beberapa tulisan sebelumnya antara lain tulisan yangberjudul
"Desain Sistem Presidensial Yang Efektif yang ditulis oleh Retno Saraswati yang lebih menyoroti terkait adanya multi partai sehingga perlu dibangun desain yang efektif sedangkan dalam tulisan ini menyoroti beberapa hal yang belum sinkron terit dianutnya sistem presidensiil Indonesia serta implikasinya dalam sistem ketatanegaraan Indonesia.

\section{B. Pembahasan}

\section{Persoalan-persoalan yang Masih Tertinggal dalam Rangka Purifikasi Sistem Presidensial serta Implikasinya dalam Sistem Ketatanegaraan Indonesia}

Sebagaimana kita ketahui, bahwa secara konvensional sistem pemerintahan yang dianut negara-negara demokrasi adalah sistem parlementer dan sistem presidensial, meskipun selain kedua sistem ini terdapat bentuk lainnya sebagai variasi disebabkan situasi dan kondisi yang berbeda sehingga melahirkan bentukbentuk semu dari kedua sistem di atas yaitu quasi parlementer dan quasi presidensial.

Dalam sistem pemerintahan parlementer hubungan antara eksekutif dan badan perwakilan sangat erat, hal ini disebabkan adanya pertanggung jawaban para menteri terhadap parlemen, dan kabinet yang dibentuk harus mendapat dukungan kepercayaan suara terbanyak dari parlemen.Dalam sistem presidensial eksekutif tidak bergantung pada badan perwakilan rakyat. Dasar hukum dari kekuasaan eksekutif dikembalikan kepada rakyat (Kusnardi, 1983).

Apabila dibandingkan antara sistem pemerintahan presidensial dengan sistem pemerintahan parlementer maka ada beberapa perbedaan yang sangat signifikan, perbedaan tersebut antara lain (Mahmuzar, 2010): Pertama, dalam sistem pemerintahan parlementer kepala pemerintahan biasanya dijabat oleh perdana menteri, pemerintahan adalah eksekutif yang bergantung pada kepercayaan legislatif, sedangkan dalam sistem pemerintahan presidensial kepala pemerintah disebut dengan presiden, dipilih dalam masa jabatan tertentu yang telah ditentukan dalam konstitusi dan dalam keadaan normal tidak dapat dipaksa untuk 
mengundurkan diri oleh badan legislatif kecuali dengan impeachment. Kedua, Kepala pemerintahan dalam sistem presidensial dipilih oleh rakyat secara langsung, sedangkan dalam parlementer kepala negara berasal dari partai pemenang pemilu. Ketiga, sistem pemerintahan parlementer mempunyai eksekutif kolegial, Perdana Menteri dan menteri-menteri bartanggung jawab sendirisendiri maupun bersama-sama kepada parlemen, sedangkan dalam sistem pemerintahan presidensial pemerintah adalah eksekutif tunggal yaitu presiden.

Kedua sistem pemerintahan yang ada yaitu parlementer dan presidensial tentunya mempunyai kelebihan dan kekurangan, yang dapat dirinci sebagai berikut: Kelebihan sistem presidensial, stabilitas eksekutif didasarkan pada masa jabatan presiden. Dianggap lebih demokratis karena pemilihan kepala pemerintahan langsung dilakukan oleh rakyat melalui pemilihan langsung, kekuasaan presiden menjadi lebih legitimate karena mendapat mandat langsung dari rakyat. Ada suatu pemisahan kekuasaan yang jelas yang berarti kekuasaan pemerintah dibatasi sehingga secara tidak langsung lebih memberikan perlindungan kepada rakyat. Kelebihan sistem parlementer, jarang terjadi konflik antara pemerintah dengan parlemen, penyesuaian antara eksekutif dan legislatif mudah dicapai.

Adapun kelemahan dari kedua sistem pemerintahan ini adalah sebagai berikut (Mahmuzar, 2010): Kelemahan dalam sistem presidensial, sering mengalami jalan buntu apabila terjadi konflik antara eksekutif dan legislatif, pemerintah dalam sistem presidensial bersifat kaku karena dibatasi masa jabatan. Sedangkan kelemahan sistem parlementer adalah kurang memberi perlindungan pada rakyat dikarenakan pemerintah berasal dari partai mayoritas, sehingga rentan terjadi persekongkolan sehingga mengingkari aspirasi rakyat, pemerintahan cenderung tidak stabil karena apabila terjadi konflik antara legislatif dan eksekutif pemerintah dapat dijatuhkan lewat mosi tidak percaya oleh parlemen.
Dalam sejarah ketatanegaraan bangsa Indonesia pernah menganut sistem pemerintahan parlementer yang didasarkan pada UUD Sementara 1950, dianutnya sistem pemerintahan parlementer dianggap merupakan sejarah buruk dan dianggap sebagai suatu pengalaman traumatis. Tanggal 5 Juli 1959 melalui Dekrit Presiden pemerintah kembali menggunakan UUD 1945 sebagai Konstitusi Negara. Dalam konstitusi ini memang memang tidak disebutkan secara tegas tentang sistem pemerintah yang dianut sehingga menimbulkan beberapa penafsiran mengenai hal ini. Satu kelompok mengatakan bahwa sebenarnya sistem pemerintahan yang dianut dalam UUD 1945 adalah sistem presidensial, dengan mendasarkan pada alasan pada kriteria sebagai berikut (Manan, 2000): (a) Presiden adalah Kepala Pemerintahan; (b) Ada kepastian masa jabatan yaitu lima tahun; (c) Presiden tidak bertanggung jawab kepada DPR; (d)Presiden tidak dapat membubarkan DPR.

Di sisi lain ada kelompok pakar yang mengatakan bahwa sistem pemerintahan yang dianut dalam UUD 1945 adalah sistem pemerintahan campuran dengan mendasarkan pada kriteria sebagai berikut (Sri Soemantri, 2001): (a) Presiden diangkat dan dipilih oleh MPR; (b) Presiden adalah mandataris MPR; (c) MPR adalah pemegang kekuasaan tertinggi; (d) Presiden tunduk dan bertangggng jawab pada MPR .

Mendasarkan beberapa kriteria ini Sri Soemantri mengatakan biasanya kriteria ini lazim ada di sistem pemerintahan parlementer, dan jika Presiden sebagai eksekutif mendapatkan pengawasan langsung dari badan legislatif maka sistem pemerintahan yang dianut adalah parlementer . Di samping dalam UUD 1945 terlihat ada anasir parlementer, juga terlihat ada anasir presidensial bahwa presiden merupakan pemegang kekuasaan pemerintah. Berdasarkan alasan-alasan inilah dikatakan bahwa sistem pemerintahan yang ada dalam UUD 1945 adalah sistem campuran.

Ketidakjelasan sistem pemerintahan yang dianut dalam UUD 1945 inilah yang mendorong dilakukannya penegasan sebenarnya sistem pemerintahan apa yang 
dianut dalam UUD 1945, dan MPR hasil pemilu 1999 menyepakati untuk mempertahankan sistem pemerintahan presidensial dengan alasan-alasan yang sudah diuraikan di atas. Berkaitan dengan hal ini maka dilakukan upaya-upaya untuk mencapai purifikasi presidensial, upaya demikian nampak dalam setiap perubahan UUD 1945. Adapun upaya yang sudah dilakukan dalam ragka melakukan purifikasi presidensial antara lain (Isra, 2010): (1) Mengubah proses pemilihan presiden dan wakil presiden dari mekanisme sistem pemilihan di MPR menjadi pemilihan secara langsung; (2) Membatasi periodisasi masa jabatan presiden dan wakil presiden; (3) Memperjelas mekanisme pemakzulan (impeachment); (4) Larangan bagi presiden untuk membubarkan DPR; (5) Memperbaruhi atau menata ulang eksistensi MPR; (6) Melembagakan pengujian undangundang (judicial review).

Mekipun telah dilakukan upaya masih ada hal-hal yang masih belum mendukung pelaksanaan sistem presidensiil, yaitu antara lain terlihat pengaturan kewenangan presiden dalam fungsi legislasi serta ketidak sinkronan antara sistem pemerintahan dengan sistem kepartaian yang dianut.

\section{Mekanisme Legislasi Amandemen}

Salah satu alasan dilakukannya perubahan UUD 1945 adalah sistem ketatanegaran yang yang ada dianggap kurang sesuai dengan sistem presidensiil yaitu antara lain adalah adanya pemberian kekuasaan yang besar kepada eksekutif (executive heavy) sehingga terjadi kekhawatiran adanya penumpukan kekuasaan pada satu cabang kekuasaan dan tidak dapat berjalannya mekanisme checks and balances. Peran eksekutif yang begitu dominan apabila dibanding dengan legislatif tampak dalam proses legislasi hal demikian terlihat dalam Pasal 5 ayat (1) UUD 1945 sebelum amandemen bahwa "Presiden memegang kekuasaan membentuk undangundang dengan persetujuan DPR “ serta dalam penjelasannya dikatakan bahwa, "Presiden bersama-sama dengan Dewan Perwakilan Rakyat menjalankan "legislative power" dalam negara. Demikian juga ketentuan yang terdapat dalam Pasal 21 ayat (2) Jika rancangan itu meskipun disetujui oleh Dewan Perwakilan Rakyat, tidak disahkan oleh Presiden, maka rancangan tadi tidak boleh dimajukan lagi dalam persidangan Dewan Perwakilan Rakyat masa itu.

Ketentuan yang tecantum dalam Pasal 5 ayat (1) UUD 1945 merupakan salah satu pasal yang tidak sesuai dengan sistem presidensial yag ada. Berkaitan dengan hal ini Ismail Suny menyatakan bahwa,"Pasal 5 ayat (1) UUD 1945 tersebut menyerupai fungsi legislasi dalam negara-negara yang menggunakan sistem pemerintahan parlementer (Sunny, 2000). Pendapat senada juga diungkapkan oleh Moh.Kusnardi dan Harmaily Ibrahim, jika ketentuan yang terdapat dalam Pasal 5 ayat (1) dihubungkan dengan Pasal 21 ayat (2) sebelum perubahan, UUD 1945 dianggap tidak sepenuhnya menganut sistem pemerintahan presidensial karena presiden dan DPR bersama-sama membuat undang-undang (Kusnardi, 1983).

Berkaitan dengan beberapa alasan di atas maka sebagai upaya untuk pemurnian sistem presidensial maka dianggap perlu untuk merubah ketentuan-ketentuan tersebut. Dalam perubahan pertama UUD 1945 ketentuan Pasal 5 ayat (1) UUD NRI tahun 1945 akhirnya di ubah menjadi "Presiden berhak mengajukan rancangan undang-undang kepada Dewan Perwakilan Rakyat", Pasal 20 ayat (1) UUD NRI tahun 1945 diubah menjadi "Dewan Perwakilan Rakyat memegang kekuasaan membentuk undang-undang“".

Perubahan kedua pasal tersebut secara substansial dianggap sebagai pergeseran yang besar dalam kekuasaan legislatif atau kekuasaan membentuk undang-undang yaitu dari presiden ke DPR. DPR dianggap mempunyai kedudukan yang lebih kuat dalam penggunaan fungsi legislatif. Apabila kita lihat dari perubahan kedua pasal di atas memang ada suatu perubahan besar dalam fungsi legislasi yaitu pergeseran dominasi fungsi legislasi dari eksekutif ke legislatif, namun demikian pengaturan fungsi legislasi pasca amandemen UUD 1945 belumlah seluruhnya sesuai dengan sistem presidensial yang dianut, dominasi fungsi legislasi di tangan legislatif 
tidak lagi tampak ketika kita melihat pengaturan yang ada dalam Pasal 20 ayat (2) dan Pasal 20 ayat (3) UUD NRI tahun 1945. Pasal 20 ayat (2) UUD NRI tahun 1945 menyatakan bahwa; "Setiap rancangan undang-undang dibahas oleh DPR dan Presiden untuk mendapat persetujuan bersama" dan Pasal 20 ayat (3) UUD NRI tahun 1945 menyatakan "Jika rancangan undang-undang itu tidak mendapat persetujuan bersama, rancangan undang-undang itu tidak boleh diajukan lagi dalam persidangan Dewan Perwakilan Rakyat masa itu". Berkaitan dengan hal ini Saldi Isra mengatakan bahwa apabila dilihat dari ketentuan kedua pasal ini berarti bahwa DPR tidak lebih kuat atau dominan dibandingkan dengan presiden dalam fungsi legislasi (Isra, 2010). Lebih lanjut dikatakan bahwa sistem pemerintahan presidensial Indonesia setelah perubahan UUD 1945 membagi ultimate authority yang seharusnya hanya dimiliki oleh lembaga perwakilan (DPR) menjadi otoritas ganda yang dimiliki oleh DPR dan Presiden (Isra, 2010).

Ketentuan di atas apabila dikaitkan dalam rangkaian proses yang harus dilalui dalam pembuatan suatu undang-undang yang antara lain terdiri dari perencanaan, pengusulan, pembahasan, persetujuan, serta pengesahan (Yohanes Nafta Irawan, 2019), maka persoalan fungsi legislasi ada pada tatanan persetujuan. Ketidak konsistenan dalam fungsi legislasi dengan Berkaitan dengan hal ini Saldi Isra mengatakan bahwa hasil perubahan UUD 1945 mengandung pola pembahasan bersama antara DPR dan Presiden sebagaiamana yang dipraktikkan sebelum perubahan (Isra, 2010).

Berdasar beberapa hal inilah bahwa dalam pengaturan fungsi legislasi dalam UUD 1945 pasca amandemen masih ada beberapa ketentuan yang menunjukkan adanya ketidak konsistensian dengan sistem presidensial yang dianut.

\section{Sistem Multipartai Yang Dianut Dalam Sistem Kepartaian}

Berbicara tentang sistem kepartaian UUD

NRI tahun 1945 tidak menyebutkan secara eksplisit apakah kita menganut sistem multi partai atau tidak. Sistem kepartaian hanya secara implisit tersirat dalam Pasal 6 A (2)
UUD NRI tahun 1945 yang menyebutkan bahwa; "Pasangan calon Presiden dan Wakil Presiden diusulkan oleh partai politik atau gabungan partai politik peserta pemilihan umum sebelum pelaksanaan pemilihan umum". Istilah gabungan partai politik dalam prakatek di artikan dua atau lebih partai politik dan dalam kenyataannya sistem kepartaian kita menganut sistem banyak partai atau yang dikenal dengan istilah sistem multi partai.

Sistem muti partai sangatlah tidak lazim atau bahkan sulit diterapkan dalam pemerintahan yang menganut sistem pemerintahan presidensial, mengingat dalam sistem presidensial antara presiden dan lembaga legislatif sama-sama dipilih secara langsung oleh rakyat dengan melalui pemilihan yang berbeda. Hal ini berarti bahwa antara legislatif dan presiden sama-sama mendapat mandat langsung dari rakyat. Sitem multi partai seringkali menimbulkan dampak adanya perpecahan suara sehingga, kemenangan presiden dalam pemilihan umum tidak serta merta diikuti kemenangan partai politik presiden di legislatif. Meski presiden memenangkan pemilihan umum tetapi tidak jarang partai politik presiden merupakan kekuatan minoritas di lembaga legislatif. Perbedaan partai mayoritas di lembaga legislatif dengan partai politik presiden inilah yang sering menimbulkan ketegangan dalam kedua lembaga ini. Ketegangan yang berkepanjangan dapat menimbulkan akibat buruk terhadap stabilitas demokrasi dan pemerintahan yang efektif.

Dalam sistem presidensial dukungan parlemen kepada presiden sangat berpengaruh di dalam proses pembuatan undang-undang dan pelaksanaan kebijakan dan programprogram pemerintah. Dalam sistem multipartai kekuatan politik mempunyai kecenderungan tersebar, sehingga kekuatan mayoritas akan sulit tercapai (Sarawati, 2012). Dalam hal presiden tidak dapat dukungan mayoritas di lembaga legislatif maka dalam praktik upaya yang sering dilakukan adalah melakukan koalisi. Berkaitan dengan hal ini Saldi Isra mengatakan, "Koalisi merupakan langkah yang biasa dibangun presiden yang tidak mempunyai dukungan mayoritas di lembaga 
legislatif, langkah ini merupakan langkah darurat yang tidak mungkin dihindarkan" (Isra, 2010).

Kompensasi dari sebuah koalisi ini biasanya diikuti dengan pembagian posisi menteri kabinet pada partai politik. Hal inilah yang menimbulkan praktek ketatanegaraan yang tidak sehat. Mahfud MD mengatakan bahwa tidak sinkonnya sistem pemerintahan dengan sistem kepartaian menimbulkan praktek sandera antara presiden dengan partai politik (kursif penulis) (Moh. Mahfud, 2009). Praktik saling sandera berpengaruh pada penyusunan menteri dalam kabinet, pelaksanaan impeachment serta pelaksanaan fungsi legislasi serta implementasi kebijakankebijakan pemerintah.

Dampak negatif ini terlihat salah satunya adalah dalam penyusunan kabinet, meskipun pengangkatan menteri merupakan hak prerogatif presiden namun dalam kenyataan penyusunannya, presiden dihadapkan pada kondisi "pendiktean" dari masing-masing parpol. Sebagian besar kursi kabinet dibagi berdasarkan kehendak parpol pendukung, sehingga proses fit and proper test dalam pemilihan calon menteri tidak terealisasi (Moh. Mahfud, 2009). Tidak dilaksanakannya uji fit and proper test tentunya dapat berdampak pada kualitas kinerja seorang menteri, kadangkala dijumpai menteri tidak mampu untuk melaksanakan tugasnya sesuai yang diharapkan, yang pada akhirnya dihadapkan pada suatu pilihan reshuffle, pelaksanaan reshuffle pada kenyataannya juga tidak dapat dilakukan dengan baik karena adanya ancaman dari parpol untuk menarik dukungan kepada presiden jika menterinya dicopot dari kabinet.

Sikap presiden untuk tunduk pada parpol menjadi hal yang dapat dimengerti karena konstitusi dan sistem politik kita tidak menjamin presiden yang dipilih langsung didalam sistem presidensial model Indonesia dapat aman dari ancaman penjatuhan (impaechment) (Moh. Mahfud, 2009). Pasal 7 A UUD NRI tahun 1945 mengatur bahwa Presiden dan atau Wakil Presiden dapat diberhentikan dalam masa jabatannya oleh Majelis Permusyawaratan Rakyat atas usul
Dewan Perwakilan Rakyat, jika terbukti melakukan pelanggaran hukum berupa pengkhianatan terhadap negara, korupsi, penyuapan, tindak pidana berat lainnya atau perbuatan tercela maupun apabila terbukti tidak lagi memenuhi syarat sebagai Presiden dan Wakil Presiden. Mekanisme pemberhentian Presiden dan Wakil Presiden diatur dalam Pasal 7 B bahwa usul pemberhentian Presiden dan Wakil Presiden dapat diajukan DPR ke MPR setelah meminta lebih dahulu Mahkamah Konstitusi untuk memutus usul dari DPR ini. Pengajuan permintaan DPR ke Mahkamah Konstitusi ini hanya dapat dilakukan dengan dukungan sekurang-kurangnya $2 / 3$ dari jumlah anggota DPR yang hadir dalam sidang paripurna dan dihadiri sekurang-kurangnya 2/3 dari anggota DPR. Keputusan MPR atas usul pemberhentian Presiden dan Wakil Presiden harus diambil dalam rapat paripurna MPR yang dihadiri sekurang-kurangnya $3 / 4$ dari jumlah anggota dan disetujui oleh sekurangkurangnya $2 / 3$ dari jumlah anggota yang hadir.

Mesipun mekanisme penjatuhan Presiden dan Wakil Presiden sebagaimana yang tercantum dalam Pasal 7 B terlihat sulit tetapi dihadapkan pada sistem kepartaian multi partai yang dianut sekarang hal tersebut menjadi tidak sulit. Jika suatu alasan politik menghendaki adanya penjatuhan Presiden dan Wakil Presiden, dengan sisem multi partai parpol dapat dengan mudah menggalang dukungan untuk melakukan impeachment kepada Presiden dan Wapres. Dengan sistem multi partai kedudukan Presiden dan Wakil Presiden tidak dapat sekuat di dalam sistem dwi partai. Dengan kondisi sistem politik yang demikian, dalam rangka menghindari adanya impeachment, suatu langka yang wajar jika Presiden akan berusaha untuk menggalang dukungan pada parpol jangan sampai syarat kuantitatif jumlah anggota DPR terpenuhi. Hal inilah yang kemudian menjadi sebab sistem presidensial tidak dapat berjalan secara murni.

Proses penggalangan dukungan yang dilakukan presiden terhadap parpol sebagai konsekuensi adanya sistem multi partai yang berdampak negatif ini tidak hanya dimaksudkan untuk menghindari adanya 
impeachment tetapi juga dalam rangka mencari dukungan untuk melancarkan proses legislasi yang diajukan Presiden serta kelancaran implementasi dari kebijakankebijakan Presiden yang dibuat.

Praktek-praktek inilah yang oleh Mahfud MD dikatakan bahwa Presiden dan Parpol saling sandera, sistem multi partai menyebabkan Presiden tidak dapat mengabaikan parpol-parpol, sehingga sistem presidensial yang ada sekarang tidak dapat mengelak untuk tampil bergaya parlementer (Moh. Mahfud, 2009).

\section{Simpulan}

Pasca amandemen UUD 1945, ternyata masih ada beberapa persoalan yang tersisa dalam rangka purifikasi sistem pemerintahahan presidensial dalam arti bahwa masih ada beberapa hal yang masih belum mendukung pelaksanaan pemurnian sistem pemerintahan presidensial yang di anut. Hal demikian terlihat dalam proses legislasi, presiden dalam proses legislasi masih memegang legislatif power yang tidak lazim ada dalam sistem presidensial. Demikian juga sistem kepartaian kita, sistem multi partai sangatlah tidak tepat diterapkan dalam sistem pemerintahan presidensial, sistem multi partai dalam kenyataannya memunculkan praktekpraktek pemerintahan yang justru mengarah pada sistem parlementer.

\section{DAFTAR PUSTAKA}

Attamimi, H. s. (2009). Peranan Keputusan Presiden Republik Indonesia Dalam Penyelenggaraan Pemerintahan Negara. Jakarta: Pasca Sarjana UI.

Isra, S. (2010). Pergeseran Fungsi Legislasi (Menguatnya Model Legislasi Parlementer Dalam Sistem Presidensial Indonesia ). Jakarta: Raja Grafindo Persada.
Jimly Asshiddiqie. (2007). Pokok-pokok Hukum Tata Negara Indonesia Pasca Reformasi. Jakarta: Buana Ilmu Populer.

Kusnardi, M. (1983). Pengantar Hukum Tata Negara Indonesia. Jakarta: Pusat Studi Hukum HTN FH UI.

Mahmuzar. (2010). Sistem Pemerintahan Indonesia Menurut UUD 1945 Sebelum dan Sesudah Amandemen. Bandung: Nusa Media.

Manan, B. (2000). Pertumbuhan Dan Perkembangan Konstitusi Negara. Bandung: Mandar Maju.

Moh. Mahfud, M. (2009). Konstitusi Dan Hukum Dalam Kontroversi Isu. Jakarta: Rajawali Press.

Moh.Mahfud, M. (1993). Dasar dan Struktur Ketatanegaraan Indonesia. Yogyakarta: UII Press.

Mustafa, B. (2001). Sistem Hukum Administrasi Negara Indonesia. Bandung: Citra Aditya Bakti.

Ranuwijaya, U. (2001). Hukum Tata Negara Indonesia. Jakarta: Ghalia Indonesia.

S.Sunarto. (2016). Prinsip Checks and Balances Dalam Sistem Ketatanegaraan Indonesia. Masalah-Masalah Hukum, 45(2), 158.

Sarawati, R. (2012). Desain Sistem Pemerintahan Presidensial Yang Efektif. Masalah-Masalah Hukum, 41, 138.

Sri Soemantri. (1997). Prosedur dan Sistem Perubahan Konstitusi. Bandung: Alumni.

Sri Soemantri. (2001). Sistem-sistem Pemerintahan Negara-negara ASEAN. Bandung: Tarsito.

Sunny, I. (2000). Pergeseran Kekuasaan Eksekutif. Jakarta: Aksara Baru.

Yohanes Nafta Irawan, E. a. (2019). Analisis Yuridis Putusan Mahkamah Konstitusi Nomor 16/PUU-XVI/2018 Tentang Pembatalan Perluasan Kewenangan Mahkamah Kehormatan Dewan. Masalah-Masalah Hukum, 48, 71. 